\title{
Is Origin Denomination an Important Marketing Strategy? The Case of Spanish Wine Industry
}

\author{
Luis Navarro Elola, Universidad de Zaragoza España \\ Jesús Pastor Tejedor, Universidad de Zaragoza España \\ Ana Clara Pastor Tejedor, Universidad de Zaragoza España \\ Adrian Archanco Olcese, Universidad de Zaragoza España
}

\begin{abstract}
This investigation work consists on an analysis with the model European Customer Satisfaction Index (ECSI), in order to know the influence that has belonging to an Origin Denomination in the wine sector. So, we've made a marketing research directed to the particular case of Somontano's Wine Origin Denomination which acts as an "umbrella" brand for many wineries of Aragón (Spain). Simultaneously these wineries have their wines under different brands. This study tries to find out if to belong to a DO benefits the wineries. Possibly "strong" wineries improve the image of Somontano's DO and other wineries of the zone. Young wineries benefit themselves with the image old ones have earned. It brings us to a question about if DO Somontano and their customers satisfaction are related or not. Model ECSI allows us to determine consumers' satisfaction aabout a certain product or service. It also demonstrates the relations existing between satisfaction and other factors that take part on purchase.
\end{abstract}

JEL codes: C12, D12, M31

\section{Introduction}

Although we all know that wine is a very present and important product in numerous countries, it is also something much more complex. It is not just another agrarian product.

A great number of people depend direct and indirectly on wine, but we dare to say it brings a "problem" with itself; wine is considered food and spirit at the same time. It has to be taken into account everything which is behind a wine bottle: the fight of the winegrowers to get wine considered as food because of its beneficial and highly demonstrated properties for health opposing the consideration of spirit it is sometimes given, as if it were simple liquor.

This corresponds with the image of the wine consumers have: they consider wine as a healthy drink and look for good quality.

But, when buying wine, what do consumers have into account, the DO or the price? Are flavor and DO the most influential factors in the decision between two wines?

In this study we try to answer these and other questions analyzing the influence the DO has in wine sector.

Present international wine market is in a new consumption dimension; and it is because its evolution has been very different according to two different categories of wine. The table wine, valued like caloric product and of daily consumption, has been losing market share vs. quality wine protected under the DO, with more important cultural components.

Some fundamental characteristics could be stood out therefore to explain why wine consumers are after quality wines:

- Slow convergence of the consumption ratios per capita between countries: homogenization between producer and no producer countries.

- Increase of the rivalry with other drinks that act like substitute products, occupying the traditional place of wine in daily life.

- The world-wide wine production is characterized in addition by the existence to two 
models (the traditional producers and the emergent ones) with some differences:

- European production is mainly based on DO and very regulated indicators of quality. The production in new producing countries is much more liberalized, and they are after strong marks and varietal wines.

- European model tries to obtain competitive advantage through the quality. However, the strategy of the emergent countries companies is based on getting a lower and homogeneous quality.

The administrative concession of a DO to a certain geographic zone, not only tries to protect the name of the region, it also implies the creation and application of a regulation that ensures a quality product.

The DO can be considered as a "collective or umbrella brand", protecting smaller brands but giving them total freedom to develop their communication and marketing policies.

Due to the existing general ignorance among the usual or potential consumers, it would be said that in many cases the DO is not able to assure "confidence to the consumers". This consumers' degree of ignorance and the great emphasis that different institutions are doing in the subject of the DO, has lead us to the accomplishment of an empirical investigation.

\section{The wine sector}

\subsection{Wine in the international context}

World-wide wine market has as the most important players the European Union countries. This is because the three first producing countries of the world, France, Italy and Spain "play in their team". France and Italy are also two of the three first consumers.

World-wide wine consumption, which increased between 1956 and 1980 from 190 million of hl to 290 million of hl, suffered an important recession between 1985 and 1995, year in which it became stabilized in 225 million of hl. Recently, there has been a slight increase until around 244 present million of hl (according to data of 2008 from the OIV).

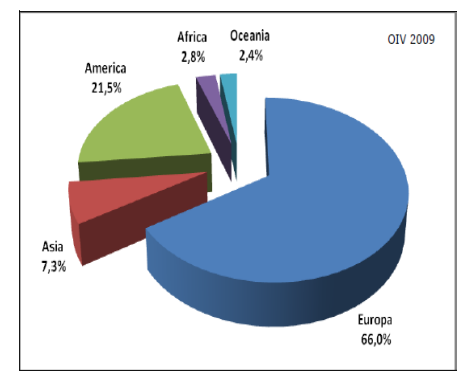

Figure 1 World consumption of wine. 2008 Fuente: OIV

\begin{tabular}{|l|r|r|}
\hline PAIS & prev. 2008 & en $\%$ \\
\hline FRANCIA & 31750 & $13,0 \%$ \\
\hline ESTADOS UNIDOS & 28516 & $11,6 \%$ \\
\hline ITALIA & 26000 & $10,6 \%$ \\
\hline ALEMANIA & 20747 & $8,5 \%$ \\
\hline CHINA & 13671 & $5,6 \%$ \\
\hline REINO UNIDO & 13483 & $5,5 \%$ \\
\hline ESPAÑA & 12790 & $5,2 \%$ \\
\hline RUSIA & 11000 & $4,5 \%$ \\
\hline ARGENTINA & 10677 & $4,4 \%$ \\
\hline RUMANIA & 5404 & $2,2 \%$ \\
\hline TOTAL MUNDIAL & $\mathbf{2 4 4 8 9 7}$ & \\
\hline
\end{tabular}

This world-wide wine consumption decrease in the last 20 years, although it is recovering step by step, is caused by the diminution of the consumption per capita of these three producer and traditionally consuming countries.

Consumption in the "new producing countries" is relatively low, overall in those with a lack of winery tradition, which gets to them to export a high percentage of its production.

These new producers, with clear exporting vocation, have been increasing market share even in the European traditional producers markets. So that, nowadays is very common to find a place for original wines from these countries in the European stores. 


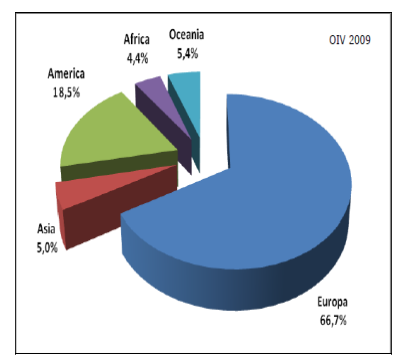

\begin{tabular}{|l|r|r|}
\hline PAIS & prev. 2008 & en \% \\
\hline ITALIA & 48633 & $18,1 \%$ \\
\hline FRANCIA & 41429 & $15,4 \%$ \\
\hline ESPAÑA & 34630 & $12,9 \%$ \\
\hline ESTADOS UNIDOS & 19200 & $7,1 \%$ \\
\hline ARGENTINA & 14677 & $5,5 \%$ \\
\hline AUSTRALIA & 12431 & $4,6 \%$ \\
\hline CHINA & 12000 & $4,5 \%$ \\
\hline SUDAFRICA & 10261 & $3,8 \%$ \\
\hline ALEMANIA & 9991 & $3,7 \%$ \\
\hline CHILE & 8683 & $3,2 \%$ \\
\hline TOTAL MUNDIAL & $\mathbf{2 6 9 0 1 8}$ & \\
\hline
\end{tabular}

Figure 2 World production of wine. 2008 Fuente: OIV

\section{Methodology}

Elaborating a causal relations model we are going to be able to establish the connection between different latent variables as client's satisfaction, loyalty, expectations, etc. But we need to assure if this model will be useful.

\subsection{European index of satisfaction of the client (ECSI)}

Model ECSI measures the satisfaction of the client in the field of the perceived quality of the services, providing a global level of the satisfaction and explaining the relations of causality with its components

\subsection{Causal definition of the variables of the model and its relations}

The first step to make the ECSI is to define the latent variables and its relations:

Expectations: level of reference that consumer of the product or service waits for, before buying it. The expectation has a direct influence on the service' perceived quality, on the service's value and on client's satisfaction.

Perceived quality: component key that determines the satisfaction of the client; it influences satisfaction through two routes:

1. Perceived quality "hardware" or quality of the "product": "hard" nucleus of the service as far as the generic characteristics of the service that is offered.

2. Perceived quality "software" or quality of the "service": specific aspects of the benefit of the service like customized attention, distribution, information services, etc.

Value of the service: relation between quality and price clients have after the received service. It acts as a link between perceived quality and satisfaction.

Image of the service: evaluates the image consumers have about our brand and company. In the model it is an exogenous or independent variable with direct influence on all the others.

Satisfaction of the client: it is the resulting variable that evaluates the attitude or psychological state of the consumer after its experience with the service.

Fidelización of the client: it is the variable of yield of the satisfaction index and measures the capacity that has the company to retain its clients, based on the level reached in that index. 


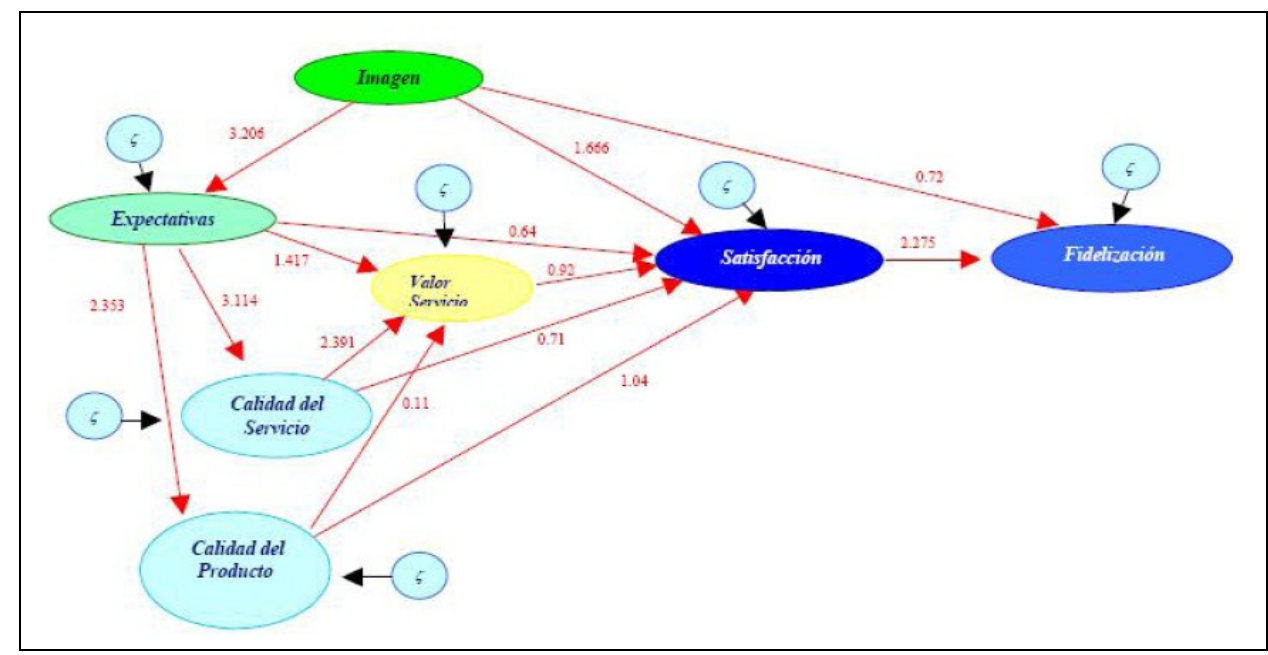

Figure 3 Model ECSI

\section{Questionnaire DO Somontano}

A questionnaire has been developed on the DO Somontano to see if the application of this type of models is guessed right in the sociological investigations or not.

$83 \%$ of the 224 people asked consume wine. So, we are going to work with this $83 \%$ in order to know their preferences, tastes, valuations, and other aspects on the denominations of origin, and more concretely on the DO Somontano.

Most of them assure they consume wine under a DO, which takes to us to corroborate that consumers look for specific requirements like quality. $82 \%$ of the people asked in our poll (152 people) usually consumes DO Somontano, 18\% doesn't.

In our study $48 \%$ assert that they ask their relatives or friends about wine when they buy some. As wine is a nutritional product, it is normal that the person who has tasted it is the one that can give better reference.

Purchase places are even more important. They are not only a place where you can buy wine, they are also a very useful advertising place where consumers can value the information that will make them to chose one product or another.

Department stores, with a 39\%, are the more visited purchase places followed by specialized stores $(27 \%)$ which receive a more "professional" client looks for a more specific product. Small supermarkets receive the $19 \%$ of the wine consumers maybe because of their accessibility. Therefore it could be a great idea to try to promote this channel.

In a society where aesthetic and design are considered as an important added value the wine sector does not want to remain aside. It is also true that as a nutritional product, its content is more important than its container. But if we have a good image, and face we will make a very big point in front of our rivals.

And as we can see, $50 \%$ give "some" or "enough" importance to the design. $21 \%$ consider design as not very important and an $8 \%$ consider it as a very important issue.

\section{Results}

The usefulness of structural equations models for social investigation is the contribution to a global vision of the aspects of the studied phenomenon, in contrast to another type of statistical tools which are focused in the individual analysis of each factor. They also reduce the amount 
of information that must be analyzed, in order to group the relations between a great number of variables.

Referring to causality study, the function of structural equations models is not to corroborate the causal relations between the different variables, but to provide its analysis and decision making.

\section{Conclusions}

Model ECSI let us to determine the consumer's satisfaction with a product or service. It also demonstrates the relations between satisfaction and other factors that take part in the purchase. Therefore, apart from giving value to these variables, it lets us to analyze their relations and the importance of their causality.

We can obtain several conclusions from the questionnaire like consumer's loyalty: more than $80 \%$ usually consumes wine from the DO Somontano. It comes to say that consumers trust DO and their brands.

Price usually has no influence in the choice between one DO and another. Flavor and DO are the more influent factors in the purchase of a certain wine. In a word, products earn an extra quality point when consumers have the guarantee of a DO.

It is also necessary to emphasize the importance consumers give to the bottle and label design. Although it is not a determining characteristic, it can mark the difference between two similar products. So that we don't have to neglect the design, because clients, pay attention to it and it also helps them to choose the wine.

Knowing the final destiny of the DO Somontano's wines consumption, helps us to know better our clients, and the purpose after the purchase of our product. This way we can focus our products on the necessities of our consumers. Thereby and according to the article "Genome of the wine consumer in Spain " we should consider that there are six different kinds of wine consumers: traditional, anxious city dweller, trendy, routinist, occasional interested, and social. Here, we have a very good target to work in.

From this results, we can conclude that belonging to a DO is a clear commercial expansion strategy that impels a mark and a type of wine praising its characteristics and properties giving technical, commercial and overall advertising support putting its region (Somontano in this case) in the map.

A perfect symbiosis arises here: regions take advantage from their wine's good image in order to develop around them a very attractive tourism for everyone.

The benefit for the DO is that many people would come to know its wines and DO Somontano knows that people consume wine when they know that wine. Somontano wants consumers agreed to the image it wants to transmit: quality.

\section{References}

- Bisquerra, R.,1989 Introducción conceptual al análisis multivariable, Barcelona.

- Carreras, 1999 Fundamentos Metodológicos de la Evaluación. La evaluación postpositiva: E.C.S.I., Tesis doctoral, Facultad de Ciencias Políticas y Sociología, Universidad Complutense de Madrid.

- Foguet, Cenders y Gallart, (2000): Modelos de Ecuaciones Estructurales Editorial La Muralla SA, Madrid.

- Hernández Calzada y Mendoza Moheno, 2008: "Decisiones de compra a partir del reconocimiento de la DO: caso del vino en la ciudad de Salamanca", Universidad de Salamanca.

- Rey, 2009 “El vino español en 2008”, Asamblea general de la Federación Española del Vino. 